\title{
CHEMICAL CONSTITUENTS OF Sinningia mauroana AND SCREENING OF ITS EXTRACTS FOR ANTIMICROBIAL, ANTIOXIDANT AND CYTOTOXIC ACTIVITIES
}

\author{
Vanessa Winiewskia , Alessandra F. Serain ${ }^{\mathrm{b}}$, Eduardo L. de Sáa, Marcos J. Salvador ${ }^{\mathrm{b}}$ and Maria Élida A. Stefanello ${ }^{\mathrm{a}, *, \bullet}$ \\ aDepartamento de Química, Universidade Federal do Paraná, 81530-900 Curitiba - PR, Brasil \\ ${ }^{b}$ Departamento de Biologia Vegetal, Instituto de Biologia, Universidade Estadual de Campinas, 13083-970 Campinas - SP, Brasil
}

Recebido em 03/08/2019; aceito em 25/11/2019; publicado na web em 17/02/2020

\begin{abstract}
Phytochemical study of aerial parts from Sinningia mauroana Chautems (Gesneriaceae) yielded 17 known compounds: sitosterol, stigmasterol, betulinic acid, oleanolic acid, hederagenin, maslinic acid, ursolic acid, pomolic acid, soranjidiol, methyl 4-hydroxyphenylacetate, 6-hydroxy-7-methoxy- $\alpha$-dunnione, 7-hydroxy-6-methoxy- $\alpha$-dunnione, jacaranone, calceolarioside A, conandroside, luteolin, and luteolin-7-O-glucoside. Complete NMR data of 6-hydroxy-7-methoxy- $\alpha$-dunnione and 7-hydroxy6-methoxy- $\alpha$-dunnione were obtained in two different solvents. Hexane, ethyl acetate and ethanol extracts were screened for antimicrobial, antioxidant and cytotoxic activities. The antimicrobial activity was assayed against Staphylococcus aureus, S. epidermidis, Escherichia coli, Pseudomonas aeruginosa, Candida albicans, C. parapsilosis, C. dubliniensis, and C. glabrata, using the microdillution method. All extracts were inactive (MIC $>100 \mu \mathrm{g} \mathrm{mL}^{-1}$ ). The antioxidant activity was evaluated with the ORAC method; the ethyl acetate and ethanol extracts were active (TE relative $>800 \mu \mathrm{g} \mathrm{g}^{-1}$ ). The cytotoxic activity was tested against PC-3 (prostate) and SKMEL-103 (melanoma) human tumor cell lines, and 3T3 fibroblast cell line, using the MTT assay. The hexane extract showed strong activity against PC-3 and SKMEL-103 human tumor cell lines $\left(\mathrm{IC}_{50}<0.25\right.$ and $3.07 \mu \mathrm{g} \mathrm{mL}{ }^{-1}$, respectively), and a lower activity towards $3 \mathrm{~T} 3$ fibroblasts $\left(\mathrm{IC}_{50}=6.84 \mu \mathrm{g} \mathrm{mL}-1\right)$. The other extracts were inactive $\left(\mathrm{IC}_{50}>50 \mu \mathrm{g} \mathrm{mL} \mathrm{L}^{-1}\right)$.
\end{abstract}

Keywords: Sinningia mauroana; Gesneriaceae; triterpenes; naphthoquinones; phenolic compounds.

\section{INTRODUCTION}

Sinningia (Gesneriaceae) is a neotropical genus of herbs and subshrubs, comprising 75 species in Brazil, distributed mainly in Southern and Southeastern regions of the country. ${ }^{1}$

Until the last decade, the knowledge about the chemical constitution of Sinningia species was scant, with only four species investigated: $S$. aggregata, $S$. allagophylla, $S$. cardinalis e $S$. speciosa. ${ }^{2}$ Since then, new phytochemical studies were carried on S. aggregata and $S$. allagophylla ${ }^{4}$ and five species were studied for the first time: S. canescens, ${ }^{5,6}$ S. hatschbachii, ${ }^{7}$ S. leucotricha,${ }^{6,8}$ S. reitzii, ${ }^{9} \mathrm{e}$ $S$. warmingii. ${ }^{10}$ The chemical profile that arises from these studies shows that the genus is very chemically diverse, producing anthraquinones, naphthoquinones and derivatives, naphthochromenes, terpenoids, flavonoids, cyclohexylethanoids, and phenylethanoid glycosides..$^{2-10}$

Some compounds isolated from Sinningia spp exhibit biological activity. The naphthoquinone dunniol, obtained from S. allagophylla, showed strong cytotoxic activity against glioma (U251), breast (MCF-7), ovarian (OVCAR-3), and ovarian resistant (NCI-ADR/ RES) human tumor cell lines. ${ }^{2}$ This plant also furnished the naphthochromene 8-methoxylapachenol, which showed antiinflammatory and antinociceptive activities. ${ }^{11}$ From $S$. reitzii, two naphthoquinones with biological activity were isolated: 6,7-dimethoxydunnione that inhibited strongly the grow of prostate (PC-3) and cervix (HeLa) human tumor cell lines, and 8-hydroxydehydrodunnione, which showed anti-inflammatory and antinociceptive activities. ${ }^{9}$ Aggregatin D, a naphthoquinone derivative isolated of $S$. aggregata and $S$. warmingii, showed antinociceptive activity, ${ }^{12}$ and cytotoxic activity against ovarian (OVCAR-03) human tumor cell line. ${ }^{3}$ Finally, the naphthoquinone 7-hydroxy6-methyoxy- $\alpha$-dunnione, obtained of S. canescens, S. leucotricha and $S$. hatschbachii, displayed anti-inflammatory and antipyretic

*e-mail: elida@ufpr.br activities. ${ }^{13}$ Therefore, Sinningia species are a still not fully exploited source of compounds with biological activity.

As part of our research project on Brazilian Sinningia, we reported here the first chemical and biological study of $S$. mauroana Chautems. This plant is a perennial subshrub $(50-230 \mathrm{~cm}$ in height) that either lacks tubers or displays only one reduced tuber. S. mauroana can be considered an ornamental species, because it is a very beautiful plant that produces red-orange flowers from March to November. Its occurrence is restricted to the Coastal Atlantic Forest in the São Paulo and Paraná states (Brazil). ${ }^{14}$ Vernacular names or uses in the folk medicine were not found for S. mauroana.

\section{EXPERIMENTAL}

\section{General procedures}

Optical rotations were measured in $\mathrm{CHCl}_{3}$ on a JASCO PTC-203 polarimeter $\left(\lambda=589 \mathrm{~nm}\right.$, temperature $\left.=20^{\circ} \mathrm{C}\right)$. Optical density was measured using a Synergy 2 (Bio-Tek) spectrophotometer. Onedimensional $\left({ }^{1} \mathrm{H},{ }^{13} \mathrm{C}\right)$ and two-dimensional (gHSQC, gHMBC) NMR spectra were recorded on Brucker spectrometers (AC 200, Avance 400 , and or Avance 600) observing ${ }^{1} \mathrm{H}$ at 200, 400, or $600 \mathrm{MHz}$, and ${ }^{13} \mathrm{C}$ at 50,100 or $150 \mathrm{MHz}$. Deuterated acetone (acetone- $d_{6}$ ), chloroform $\left(\mathrm{CDCl}_{3}\right)$ or methanol $\left(\mathrm{MeOH}-d_{4}\right)$ were used as solvents, and the chemical shifts are given in ppm $(\delta)$, with coupling constants $(J)$ in Hz. TMS was used as internal reference. Geometry optimization and density functional theory (DFT) calculations on the electronic structure of the compounds employed B3LYP functional, having Los Alamos ECP as basis set as implemented in Gaussian suite program. Theoretical optical rotations were calculated after geometry optimization. ${ }^{15}$ HPLC separations were performed in a Waters apparatus equipped with PDA detector, and a semi-preparative Nucleosil 100-5 C18 column ( 250 x $10 \mathrm{~mm})$. Acetonitrile:water 40:60 (isocratic) was used as mobile phase, with a flow rate of $2.8 \mathrm{~mL} \mathrm{~min}^{-1}$, 
at room temperature, applied for $25 \mathrm{~min}$. Column chromatographic separations (CC) were carried on silica gel 60 (Merck, 230-400 mesh) or sephadex LH-20 (Sigma Co), while precoated silica gel $60 \mathrm{GF}_{254}$ plates (Macherey-Nagel) were used for TLC and preparative TLC (PTLC). Compounds were visualized by exposure under $\mathrm{UV}_{254 / 365}$ light and spraying with $5 \%(\mathrm{v} / \mathrm{v}) \mathrm{H}_{2} \mathrm{SO}_{4}$ in ethanol solution, followed by heating on a hot plate. All solvents were analytical or spectroscopic grade, and the mixtures of solvents were prepared as v/v.

\section{Plant material}

Stems of Sinningia mauroana Chautems were cut off from a natural population in Antonina, Paraná State, Brazil (25²5'44" S; 48 42'43” W), in March/2013. The plant was collected and identified by Clarice B. Poliquesi, who deposited a voucher specimen in the Herbarium of Museu Botânico Municipal (MBM 391.575). The stems were cultivated in Curitiba, Paraná State, Brazil (25 26'34.85" S, $\left.49^{\circ} 14^{\prime} 22.58^{\prime \prime} \mathrm{W}\right)$. Aerial parts for phytochemical study were collected from these cultivated plants in March/2015. The access was registered on SISGEN under number AF5C97F.

\section{Extraction and isolation}

Dried and powdered aerial parts of S. mauroana (327.0 g) were extracted with hexanes (Hex, mixture of isomers), EtOAc, and EtOH, successively (three successive extraction employing 1.6 L of solvent each time), at room temperature. The solvents were removed using a rotatory evaporator, at reduced pressure, to give the respective extracts. An aliquot $(20 \mathrm{mg})$ of each extract was reserved for biological studies.

The Hex extract $(\mathrm{H}, 1.38 \mathrm{~g})$ was submitted to $\mathrm{CC}$ (silica gel) eluted with mixtures of Hex:EtOAc $(95: 5 ; 9: 1 ; 8: 2 ; 7: 3)$, EtOAc and $\mathrm{MeOH}$, yielding 11 fractions after TLC analysis $\left(\mathrm{H}_{1-11}\right)$. An aliquot (86.0 mg) of $\mathrm{H}_{6}(169.1 \mathrm{mg}$; eluted with Hex:EtOAc 9:1) yielded $1+2(23.2 \mathrm{mg}$ ) after PTLC (Hex:EtOAc 8:2). An aliquot (68.5 mg) of $\mathrm{H}_{8}$ (120.7 mg; eluted with Hex:EtOAc 8:2) gave 3 (7.2 mg) after PTLC (Hex:Me $\left.{ }_{2} \mathrm{CO} 8: 2\right)$.

The EtOAc extract (A, $1.77 \mathrm{~g}$ ) was submitted to $\mathrm{CC}$ (silica gel) eluted with mixtures of Hex:EtOAc $(95: 5 ; 9: 1 ; 8: 2 ; 7: 3$; 3:2), EtOAc, and $\mathrm{MeOH}$, yielding 13 fractions $\left(\mathrm{A}_{1-13}\right)$ after TLC analysis. Fraction $\mathrm{A}_{4}(47.5 \mathrm{mg}$, eluted with Hex:EtOAc 8:2) yielded 1+2. Fraction $A_{5}(24.4 \mathrm{mg}$, eluted with Hex:EtOAc 8:2) yielded 9 $(1.9 \mathrm{mg})$ and $\mathbf{1 0}(1.8 \mathrm{mg})$ after PTLC (Hex:EtOAc 7:3). $\mathrm{A}_{6}(23.8 \mathrm{mg}$, eluted with Hex:EtOAc 7:3) yielded 4 (4.4 mg); 4 + 7 (3.9 mg), and $\mathbf{4}+\mathbf{7}+\mathbf{8}(5.9 \mathrm{mg})$ after PTLC (Hex:Me $\mathrm{CO}_{2}$ 3:2). $\mathrm{A}_{7}$ (12.4 mg, eluted with Hex:EtOAc 7:3) contained a mixture of $\mathbf{1 1}+\mathbf{1 2}$ that was separated by HPLC, yielding 11 (4.8 $\mathrm{mg}$, retention time $=17.03 \mathrm{~min}$ ) and 12 ( $5.7 \mathrm{mg}$, retention time $=18.10 \mathrm{~min})$. Compound $13(10.8 \mathrm{mg})$ was obtained by PTLC $\left(\mathrm{CH}_{2} \mathrm{Cl}_{2}: \mathrm{MeOH} 9: 1\right)$ from $\mathrm{A}_{9}$ ( $85.1 \mathrm{mg}$, eluted with EtOAc). Fraction $\mathrm{A}_{10}(39.5 \mathrm{mg}$, eluted with EtOAc) yielded $5+\mathbf{6}$ $(5.6 \mathrm{mg})$ and $\mathbf{1 3}(1.5 \mathrm{mg})$ after PTLC $\left(\mathrm{CH}_{2} \mathrm{Cl}_{2}\right.$ :diethyl ether 1:1).

The ethanol extract (4.26 g) was dissolved in $\mathrm{H}_{2} \mathrm{O}$ :EtOH $1: 1$ $(120 \mathrm{~mL})$ and extracted with 1-butanol $(3 \mathrm{x} 40 \mathrm{~mL})$. The fraction soluble in 1-butanol (B, $2.02 \mathrm{~g}$ ) was submitted to CC (Sephadex $\mathrm{LH}-20)$ eluted with $\mathrm{MeOH}$ to give 11 subfractions $\left(\mathrm{B}_{1-11}\right) . \mathrm{B}_{7}(72.3 \mathrm{mg})$ yielded $\mathbf{1 4}(7.7 \mathrm{mg})$ and $\mathbf{1 5}(9.8 \mathrm{mg})$ after PTLC $\left(\mathrm{CH}_{2} \mathrm{Cl}_{2}: \mathrm{MeOH} 9: 1\right)$. Compounds $17(15.0 \mathrm{mg})$ and $\mathbf{1 6}(1.2 \mathrm{mg})$ were obtained from $\mathrm{B}_{10}$ (44.8 mg), by PTLC $\left(\mathrm{CH}_{2} \mathrm{Cl}_{2}: \mathrm{MeOH} 9: 1\right)$.

\section{Biological Assays}

Antimicrobial activity

The antimicrobial activity of extracts in Hex, EtOAc and EtOH was evaluated by the microdillution method (96-well plates), as previously reported. ${ }^{16}$ The following microorganisms were used: Staphylococcus aureus ATCC 14458, S. epidermidis ATCC 12228, Escherichia coli ATCC 35218, Pseudomonas aeruginosa ATCC 27853 (field strain), Candida albicans ATCC 10231, C. parapsilosis ATCC 22019, C. dubliniensis ATCC 778157, and C. glabrata ATCC 30070. The samples were tested at concentrations varying between $12.5-1000 \mu \mathrm{g} \mathrm{mL}^{-1}$, and the minimal inhibitory concentration (MIC) was calculated in $\mu \mathrm{g} \mathrm{mL}^{-1}$ as the lowest concentration showing complete inhibition of the tested strain. The assays were carried on in duplicate, and chloramphenicol and ketoconazole were used as positive controls for bacteria and fungi, respectively. The negative control was the solvent $\mathrm{H}_{2} \mathrm{O}$ :dimethylsulfoxide $\left(\mathrm{H}_{2} \mathrm{O}\right.$ :DMSO, 95:5).

\section{Antioxidant activity}

The in vitro antioxidant capacity of the extracts was measured by the ORAC-FL assay, with fluorescein as the fluorescent probe and AAPH [2,2'-azobis(2-amidinopropane) dihydrochloride] as the free radical source. The experiments were performed in 96 wells plates as previously reported. ${ }^{17}$ Sequential dilutions of the samples (5-500 $\left.\mu \mathrm{g} \mathrm{mL}^{-1}\right)$ were prepared in phosphate buffer:DMSO 99:1. Trolox (6-hydroxy-2,5,7,8-tetramethylchroman-2-carboxylic

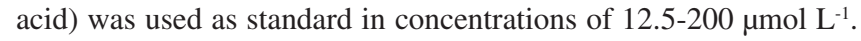
The reading was performed using a fluorescent filter (excitation $\lambda=485 \mathrm{~nm}$ and emission $\lambda=528 \mathrm{~nm}$ ) in a microplate reader, monitoring the reaction at $37^{\circ} \mathrm{C}$ every $2 \mathrm{~min}$ for a period of $70 \mathrm{~min}$. Results were expressed as $\mu \mathrm{mol}$ of trolox equivalent (TE) per gram of dried extract ( $\left.\mu \mathrm{mol} \mathrm{TE} \mathrm{g}^{-1}\right)$. Caffeic acid, chlorogenic acid, quercetin and isoquercetin were used as positive controls, while the solvent was the negative control. All experiments were performed in triplicate.

\section{Cytotoxic activity}

The cytotoxic activity of the extracts was evaluated in vitro against the human tumor cell lines PC-3 (prostate) and SKMEL-103 (melanoma), and the no cancer cell line 3T3 (fibroblast), all from the American Type Culture Collection (ATCC). The assays were performed using the MTT [3-(4,5-dimethyl-2-thiazolyl)-2,5-diphenyl2-H-tetrazolium bromide] method, as previously described.$^{18}$ Briefly, the cells were distributed in 96 -well plates $(100 \mu \mathrm{L}$ cells by well), and exposed to four different concentrations of each extract $(0.25$, $2.5,25$, and $\left.250 \mu \mathrm{g} \mathrm{mL}^{-1}\right)$ in DMSO $(0.1 \%)$ at $37{ }^{\circ} \mathrm{C}$, with $5 \%$ of $\mathrm{CO}_{2}$, for $48 \mathrm{~h}$. The final concentration of DMSO did not affect cell viability. Doxorubicin $(0.025,0.25,2.5$, and $25 \mu \mathrm{g} \mathrm{mL}-1)$ was used as the positive control, and DMSO was the negative control. The viability of cells was quantified by the ability of living cells to reduce the yellow dye MTT to a blue formazan product. At the end of $48 \mathrm{~h}$ of incubation, the culture medium was replaced by fresh medium containing $0.5 \mu \mathrm{g} \mathrm{mL}^{-1}$ of MTT. After three hours, the formazan product was dissolved in DMSO and the optical density was measured by spectrophotometry at $570 \mathrm{~nm}$. The experiments were performed in triplicate and the concentration needed to achieve $50 \%$ inhibition of cell viability $\left(\mathrm{IC}_{50}\right)$ was calculated in $\mu \mathrm{mol} \mathrm{L}^{-1}$ by non-linear regression using the GRAPHPAD program. ${ }^{19}$

\section{RESULTS AND DISCUSSION}

The extracts of aerial parts of Sinningia mauroana yielded 17 known compounds, which were identified as sitosterol (1) ${ }^{20}$ stigmasterol (2) ${ }^{20}$ betulinic acid (3), ${ }^{21}$ oleanolic acid (4), ${ }^{21}$ 23-hydroxyoleanolic acid (hederagenin, 5), ${ }^{22} 2$ - $\alpha$-hydroxyoleanolic acid (maslinic acid, 6), ${ }^{22}$ ursolic acid (7), ${ }^{21}$ 19- $\alpha$-hydroxyursolic acid (pomolic acid, 8), ${ }^{21}$ 1,6-dihydroxy-2-methylanthraquinone (soranjidiol, 9), ${ }^{23}$ methyl 4-hydroxyphenylacetate (10), ${ }^{24}$ 6-hydroxy-7-methoxy- $\alpha$-dunnione 
(11), ${ }^{25}$ 7-hydroxy-6-methoxy- $\alpha$-dunnione $(\mathbf{1 2}),{ }^{5}$ jacaranone $(\mathbf{1 3}),{ }^{26}$ calceolarioside A (14), ${ }^{27}$ conandroside (15), ${ }^{28}$ luteoline (16),${ }^{29}$ and luteoline-7-O-glucoside (17). ${ }^{30}$ Compounds $\mathbf{1 - 3}$ were isolated from the hexane extract, 4-13 from the ethyl acetate extract, and 14-17 from the fraction of the ethanol extract soluble in 1-butanol. The triterpenes 6-8, the naphthoquinone $\mathbf{1 1}$, and the flavonoids $\mathbf{1 6 - 1 7}$ are being described for the first time in Sinningia (Figure 1). All isolated compounds were analyzed by NMR (1D and 2D), and the data were compared with the literature.

Previously published NMR data of $\mathbf{1 1}$ are incomplete and disagree with our results because the spectra were recorded in different solvents, ${ }^{25}$ but the structure was confirmed by analysis of HSQC and HMBC spectra. The NMR data of the naphthoquinones $\mathbf{1 1}$ and $\mathbf{1 2}$ are very similar when obtained in the same solvent, making it difficult to discriminate between these isomers by direct comparison with the literature data. However, the distinction is possible considering mainly the chemical shifts of the aromatic hydrogens (H-5 and H-8) and of the hydroxy group. Furthermore, the correlations observed in the HMBC allow the unambiguous assignments of the aromatic hydrogens because $\mathrm{C}-1$ is more shielded than $\mathrm{C}-4 .{ }^{9}$

In the ${ }^{1} \mathrm{H}$ NMR spectrum of $\mathbf{1 1}$, recorded in $\mathrm{CDCl}_{3}$, the signals of aromatic hydrogens are observed at $\delta_{\mathrm{H}} 7.51(\mathrm{H}-8)$ and $7.53(\mathrm{H}-5)$, while in the ${ }^{1} \mathrm{H}$ NMR spectrum of $\mathbf{1 2}$ these signals are at $\delta_{\mathrm{H}} 7.51(\mathrm{H}-5)$ and $7.55(\mathrm{H}-8)$. The signal of the hydroxy group is observed at $\delta_{\mathrm{H}} 6.17$ and 6.02 in the ${ }^{1} \mathrm{H}$ NMR spectra of $\mathbf{1 1}$ and $\mathbf{1 2}$, respectively (Table 1, Figure 22S). By using a more polar solvent, as deuterated acetone, the chemical shifts of the hydroxy groups are greatly deshielded, and their signals are observed now at $\delta_{\mathrm{H}} 9.00$ (11) and 8.77 (12) (Table 2). On the other hand, the aromatic hydrogens became more shielded and with better resolution, with signals at $\delta_{\mathrm{H}} 7.39(\mathrm{H}-5)$ and $7.47(\mathrm{H}-8)$, for the compound 11, and at $\delta_{\mathrm{H}} 7.37(\mathrm{H}-8)$ and $7.48(\mathrm{H}-5)$, for the compound 12 (Table 2, Figure 28S).

The ${ }^{13} \mathrm{C}$ NMR data of $\mathbf{1 1}$ and $\mathbf{1 2}$ are very similar in both used solvents, with deuterated acetone causing small deshield effects (Tables 1 and 2, Figures 23S, 29S and 32S). For identification purpose, it is important note that hydrogenated aromatic carbons<smiles>[Y][Y][Y]</smiles>

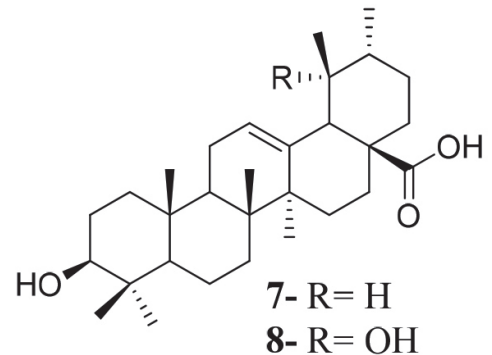

8- $\mathrm{R}=\mathrm{OH}$<smiles>COc1cc2oc3c(c(=O)c2cc1O)C(C)(C)[C@@](C)(I)C3=O</smiles>

11<smiles>C=C(C)[C@H]1CCC2(C(=O)O)CC[C@]3(C)C(CCC4[C@@]5(C)CC[C@H](O)C(C)(C)C5CC[C@]43C)C12</smiles><smiles>Cc1ccc2c(c1O)C(=O)c1ccc(O)cc1C2=O</smiles><smiles>COc1cc2c(cc1O)C(=O)C1=C(O[C@H](F)C1(F)F)C2=O</smiles>

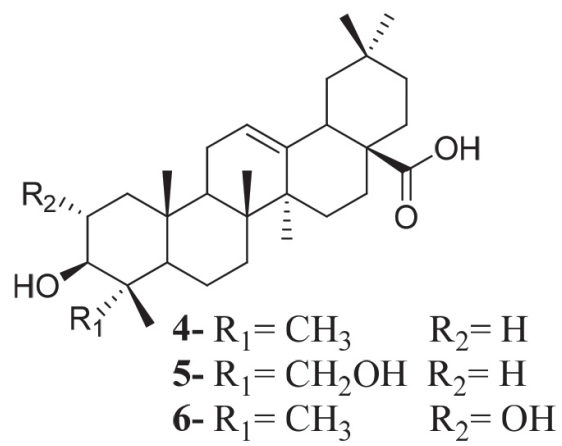<smiles>COC(=O)Cc1ccc(O)cc1</smiles><smiles>COC(=O)CC1(O)C=CC(=O)C=C1</smiles>

13

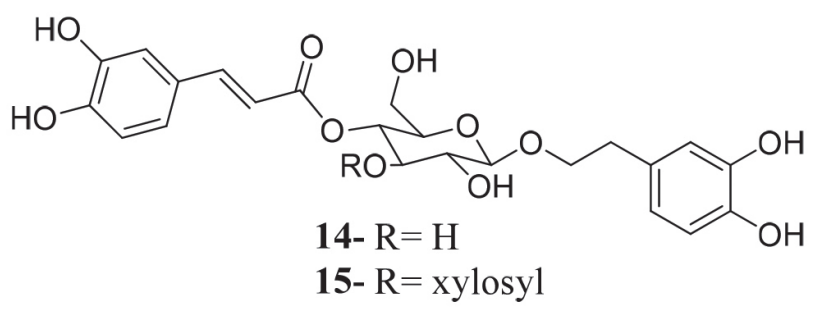<smiles>[R6]Oc1cc(O)c2c(=O)cc(-c3ccc(O)c(O)c3)oc2c1</smiles>

Figure 1. Chemical structures of isolated compounds 
(C-5 and C-8) show quite different chemical shifts, with the carbon ortho to the one bonded to the methoxy group being more shielded $\left(\delta_{\mathrm{C}} 107.8-109.4\right)$ than the carbon ortho to the one attached to the hydroxy group $\left(\delta_{\mathrm{C}} 112.3-113.0\right)$, independent of the solvent used. As the position of methoxy and hydroxy groups are changed in $\mathbf{1 1}$ and 12, the assignments of C-5 and C-8 also are inverted. Another interesting feature is the chemical shifts of oxygenated carbons (C-6 and C-7). Both show very close chemical shifts (around $\delta_{\mathrm{C}} 150$ ), but C-7 is always more protected than C-6, independent of used solvent or attached substituent (Tables 1 and 2).

The NMR assignments were corroborated by HSQC and HMBC spectra of $\mathbf{1 1}$ and 12. In the $\mathrm{HMBC}$ spectrum of $\mathbf{1 1}\left(\mathrm{CDCl}_{3}\right.$, Table 1 , Figure $25 \mathrm{~S}$ ), the hydrogen at $\delta_{\mathrm{H}} 7.51$ showed a cross-peak with a carbon at $\delta_{\mathrm{C}} 178.2$, which is typical of C-1 in the framework of the $\alpha$-dunniones, ${ }^{9}$ while the hydrogen at $\delta_{\mathrm{H}} 7.53$ showed correlation with a carbon at $\delta_{\mathrm{C}} 181.5$ that is characteristic of C-4. Therefore, the hydrogens at $\delta_{\mathrm{H}} 7.51$ and 7.53 were located at $\mathrm{C}-8$ and $\mathrm{C}-5$, respectively. The position of the methoxy group in $\mathrm{C}-7$ was deduced from correlations among $\mathrm{H}-5$ and the methoxy group (at $\delta_{\mathrm{H}} 4.02$ ) with an oxygenated carbon at $\delta_{\mathrm{C}} 149.6$ (C-7). Otherwise, in the HMBC spectrum of $\mathbf{1 2}\left(\mathrm{CDCl}_{3}\right.$, Table 1, Figure $\left.27 \mathrm{~S}\right)$ the hydrogen at $\delta_{\mathrm{H}} 7.51$ showed a cross-peak with a carbon at $\delta_{\mathrm{C}} 182.2(\mathrm{C}-4)$, while the other aromatic hydrogen $\left(\delta_{\mathrm{H}} 7.55\right)$ showed a cross-peak with a carbon at $\delta_{\mathrm{C}} 178.2(\mathrm{C}-1)$. Now, $\mathrm{H}-8\left(\delta_{\mathrm{H}} 7.55\right)$ and the methoxy group $\left(\delta_{\mathrm{H}} 4.03\right)$ showed correlations with a carbon at $\delta_{\mathrm{C}} 150.9(\mathrm{C}-$ $6)$. These and the remaining correlations (Table 1) confirmed 11 and $\mathbf{1 2}$ as isomers that differ in the position of the substituents in the aromatic ring. The same conclusion could be achieved from HSQC and HMBC spectra in deuterated acetone (Table 2, Figures $31 \mathrm{~S}$ and $34 \mathrm{~S})$.

The absolute configuration of naphthoquinones of the $\alpha$-dunnione type has been previously determinated by different methods. The octant rules were applied to analyze the CD spectra of (-)-6,8-dihydroxy7-methoxy- $\alpha$-dunnione, which had its absolute configuration determinated as $R{ }^{31}$ This conclusion was extended to levorotatory $\alpha$-dunnione and derivatives, including compound 11, which was previously isolated as the levorotatory isomer. ${ }^{25}$ Oddly, both papers show the structures for the $S$ isomer. ${ }^{25,31}$ In another approach, the $R$ absolute configuration was established for (+)- $\alpha$-dunnione by X-ray diffraction analysis of (+)-4-bromophenyl-hydrazone-dunnione. ${ }^{32}$ This result was used to assign the absolute configuration of several $\alpha$-dunnione derivatives, including compound 12. ${ }^{5,33}$ Considering these contradictory reports, we decide to use computational calculations to deduce the absolute configuration of $\mathbf{1 1}$ and $\mathbf{1 2}$. It is possible to calculate the optical rotation of a specific enantiomer employing the density functional theory (DFT) ${ }^{15}$; comparison between the calculated and experimental values leads to the assignment of absolute configuration. The optical rotation calculated for compound 11 was 125.1, with positive signal for the $S$ isomer and negative for the $R$ isomer. The experimental optical rotation measured here was -98.9 (lit. -98), ${ }^{25}$ and accordingly, this compound had its absolute configuration assigned as $R$. For compound 12, the calculated value was -127.4 for the $S$ isomer, and the experimental optical rotation was -80.7 (lit. -86.9). ${ }^{5}$ Therefore, its absolute configuration was assigned as $S$. It is remarkable that the position of distant substituent affects the signal of optical rotation of $\mathbf{1 1}$ and $\mathbf{1 2}$.

The hexane, EtOAc, and EtOH extracts were evaluated for antimicrobial, antioxidant and cytotoxic activities. The antimicrobial assays were made using Gram-positive and Gram-negative bacteria, and fungi. The hexane extract was inactive against all tested microorganisms, while the EtOAc and EtOH extracts inhibited the growth only of Gram-positive bacteria (Staphylococcus aureus and S. epidermidis), with minimal inhibitory concentration (MIC) of $250 \mu \mathrm{g} \mathrm{mL}^{-1}$ (Table 1S). These values of MIC indicate a very weak antimicrobial activity of $S$. mauroana extracts, considering the expected $\mathrm{MIC} \leq 100 \mu \mathrm{g} \mathrm{mL} \mathrm{m}^{-1}$ for significant activity of extracts. ${ }^{34}$ These results are consistent with the compounds found in each extract. Previous studies demonstrated that betulinic acid (3), isolated here from the hexane extract, was inactive toward various microorganisms, while oleanolic (4) and ursolic (7) acids, isolated now from the EtOAc extract, showed only a weak activity against Gram-positive bacteria. ${ }^{35}$ Furthermore, phenolic compounds, as

Table 1. NMR data for $\mathbf{1 1}(400 \mathrm{MHz})$ and $\mathbf{1 2}(600 \mathrm{MHz})$, in $\mathrm{CDCl}_{3}$

\begin{tabular}{|c|c|c|c|c|c|c|}
\hline \multirow{2}{*}{ position } & \multicolumn{3}{|c|}{11} & \multicolumn{3}{|c|}{12} \\
\hline & $\delta_{\mathrm{H}}$ mult. $(J$ in $\mathrm{Hz})$ & $\delta_{\mathrm{C}}$ & HМBC & $\delta_{\mathrm{H}}$ mult. $(J$ in $\mathrm{Hz})$ & $\delta_{\mathrm{C}}$ & HMBC \\
\hline 1 & & 178.2 & & & 178.2 & \\
\hline 2 & & 158.7 & & & 158.7 & \\
\hline 3 & & 130.0 & & & 130.1 & \\
\hline 4 & & 181.5 & & & 182.2 & \\
\hline 5 & $7.53 \mathrm{~s}$ & 112.3 & 4,9 & $7.51 \mathrm{~s}$ & 107.8 & $4,7,9$ \\
\hline 6 & & 150.6 & & & 150.9 & \\
\hline 7 & & 149.6 & & & 149.3 & \\
\hline 8 & $7.51 \mathrm{~s}$ & 108.0 & $1,6,10$ & $7.55 \mathrm{~s}$ & 112.3 & 1,10 \\
\hline 9 & & 125.7 & & & 126.5 & \\
\hline 10 & & 129.2 & & & 128.1 & \\
\hline 11 & & 45.6 & & & 45.2 & \\
\hline 12 & $4.56 \mathrm{q}(6.6)$ & 91.6 & 14,15 & $4.56 \mathrm{q}(6.6)$ & 91.5 & 14,15 \\
\hline 13 & $1.44 \mathrm{~d}(6.6)$ & 14.2 & 11,12 & $1.43 \mathrm{~d}(6.6)$ & 14.2 & 11,12 \\
\hline 14 & $1.27 \mathrm{~s}$ & 20.7 & $3,11,12,15$ & $1.47 \mathrm{~s}$ & 26.0 & $3,11,12,15$ \\
\hline 15 & $1.47 \mathrm{~s}$ & 25.9 & $3,11,12,14$ & $1.27 \mathrm{~s}$ & 20.6 & $3,11,12,14$ \\
\hline $\mathrm{OCH}_{3}$ & $4.02 \mathrm{~s}$ & 56.6 & 7 & $4.03 \mathrm{~s}$ & 56.5 & 6 \\
\hline $\mathrm{OH}$ & $6.17 \mathrm{~s}$ & & 5,6 & $6.02 \mathrm{~s}$ & & 7 \\
\hline
\end{tabular}


Table 2. NMR data for $11(400 \mathrm{MHz})$ and $12(600 \mathrm{MHz})$, in acetone- $d_{6}$

\begin{tabular}{|c|c|c|c|c|c|c|}
\hline \multirow[t]{2}{*}{ position } & \multicolumn{3}{|c|}{11} & \multicolumn{3}{|c|}{12} \\
\hline & $\delta_{\mathrm{H}}$ mult. $(J$ in $\mathrm{Hz})$ & $\delta_{\mathrm{C}}$ & HMBC & $\delta_{\mathrm{H}}$ mult. $(J$ in $\mathrm{Hz})$ & $\delta_{\mathrm{C}}$ & HMBC \\
\hline 1 & & 178.1 & & & 178.4 & \\
\hline 2 & & 159.6 & & & 159.5 & \\
\hline 3 & & 130.6 & & & 130.7 & \\
\hline 4 & & 182.5 & & & 182.6 & \\
\hline 5 & $7.39 \mathrm{~s}$ & 113.0 & 4,9 & $7.48 \mathrm{~s}$ & 109.0 & $4,7,9$ \\
\hline 6 & & 151.9 & & & 153.0 & \\
\hline 7 & & 151.4 & & & 152.6 & \\
\hline 8 & $7.47 \mathrm{~s}$ & 109.0 & $1,6,10$ & $7.37 \mathrm{~s}$ & 112.8 & $1,6,10$ \\
\hline 9 & & 125.5 & & & 127.3 & \\
\hline 10 & & 129.8 & & & 128.5 & \\
\hline 11 & & 45.8 & & & 45.8 & \\
\hline 12 & $4.57 \mathrm{q}(6.6)$ & 91.8 & 14,15 & $4.57 \mathrm{q}(6.6)$ & 91.8 & 14,15 \\
\hline 13 & $1.41 \mathrm{~d}(6.6)$ & 14.5 & 11,12 & $1.40 \mathrm{~d}(6.6)$ & 14.5 & 11,12 \\
\hline 14 & $1.26 \mathrm{~s}$ & 20.8 & $3,11,12,15$ & $1.46 \mathrm{~s}$ & 26.2 & $3,11,12,15$ \\
\hline 15 & $1.44 \mathrm{~s}$ & 26.2 & $3,11,12,14$ & $1.26 \mathrm{~s}$ & 20.8 & $3,11,12,14$ \\
\hline $\mathrm{OCH}_{3}$ & $4.00 \mathrm{~s}$ & 56.7 & 7 & $4.02 \mathrm{~s}$ & 56.7 & 6 \\
\hline $\mathrm{OH}$ & $9.00 \mathrm{~s}$ & & 5 & $8.77 \mathrm{~s}$ & & 7,8 \\
\hline
\end{tabular}

those present in the EtOAc and EtOH extracts, also are known to be active against Gram-positive bacteria. ${ }^{34}$ Similar results have been found for other Sinningia species, as S. hatschbachii and S. warmingii. ${ }^{7,10}$

The antioxidant capacity, measured by ORAC method, was expressed as $\mu \mathrm{mol}$ of trolox equivalent (TE) by gram of dried extract

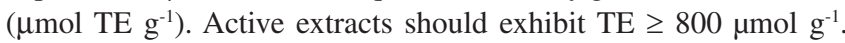
Accordingly, the EtOAc and EtOH extracts of $S$. mauroana are active, while the hexane extract is inactive (Table 3). Again, these results are consistent with the compounds isolated from each extract. Jacaranone

Table 3. Antioxidant capacity of $S$. mauroana extracts

\begin{tabular}{cc}
\hline samples & ORAC assay $(\mu \mathrm{mol} \mathrm{TE} \mathrm{g-1})$ \\
\hline Hexane extract & $215.9 \pm 0.5$ \\
EtOAc extract & $873.9 \pm 112.6$ \\
EtOH extract & $1251.2 \pm 29.2$ \\
Quercetin $^{\mathrm{a}}$ & $5.60 \pm 0.08^{\mathrm{b}}$ \\
Isoquercetin $^{\mathrm{a}}$ & $5.15 \pm 0.09^{\mathrm{b}}$ \\
Caffeic acid $^{\mathrm{a}}$ & $2.85 \pm 0.03^{\mathrm{b}}$ \\
Chlorogenic acid $^{\mathrm{a}}$ & $2.65 \pm 0.03^{\mathrm{b}}$ \\
\hline
\end{tabular}

${ }^{a}$ positive controls; ${ }^{b}$ data of pure compounds are expressed as relative trolox equivalent. The values are average of triplicate assays \pm standard deviation.
(13), obtained from EtOAc extract, showed antioxidant capacity in a previous study. ${ }^{36}$ The presence of phenolic glycosides (14-15) and flavonoids (16-17) justify the higher antioxidant activity of EtOH extract. In fact, the antioxidant capacity of phenylethanoid glycosides and flavonoids had been demonstrated by several previous studies. ${ }^{37-39}$ Calceolarioside A (14) was found to be a strong antioxidant. ${ }^{39}$ Luteolin (16) and luteolin-7-O-glucoside (17) also showed significant antioxidant capacity. ${ }^{38}$

The cytotoxic activity of the extracts was evaluated against PC-3 (prostate) and SKMEL-103 (melanoma) human tumor cell lines, besides the 3T3 (fibroblast) as cell line control. The EtOAc and EtOH extracts were considered inactive $\left(\mathrm{IC}_{50}>50 \mu \mathrm{g} \mathrm{mL}-1\right)$ (Table 4). On the other hand, the hexane extract displayed strong cytotoxic activity $\left(\mathrm{IC}_{50} \leq 10 \mu \mathrm{g} \mathrm{mL}^{-1}\right)$ against all tested cell lines. The most susceptible cell line was PC-3 $\left(\mathrm{IC}_{50}<0.25 \mu \mathrm{g} \mathrm{mL}-1\right.$ ), followed by SKMEL-03 $\left(\mathrm{IC}_{50} 3.07 \mu \mathrm{g} \mathrm{mL}^{-1}\right)$ and $3 \mathrm{~T} 3\left(\mathrm{IC}_{50} 6.84 \mu \mathrm{g} \mathrm{mL}^{-1}\right)$. In comparison with the control cell lines (3T3 - fibroblast), the hexane extract showed high selectivity toward the PC-3 (prostate) cell lines. In comparison with the positive control doxorubicine, the hexane extract was more active against SKMEL-103 cell lines and less active against the control cell line 3T3 (Table 4). These results can be explained by presence in the hexane extract of sitosterol (1) and betulinic acid (3). Previous studies showed that $\mathbf{1}$ induce apoptosis in PC-3 cell lines, ${ }^{40}$ while $\mathbf{3}$ is active against several human tumor cell lines, including metastatic melanoma and prostate..$^{41}$

Table 4. Cytotoxic activity of $S$. mauroana extracts

\begin{tabular}{lcccc}
\hline Cell line & \multicolumn{4}{c}{$\mathrm{IC}_{50}\left(\mu \mathrm{g} \mathrm{mL} \mathrm{m}^{-1}\right) \pm$ standard deviation } \\
\cline { 2 - 5 } & Hexane extract & EtOAc extract & EtOH extract & Doxo \\
\hline PC-3 (prostate) & $<0.25$ & $103.3 \pm 0.05$ & $90.25 \pm 0.08$ & $0.20 \pm 0.01$ \\
SKMEL-103 (melanoma) & $3.07 \pm 0.18$ & $>250$ & $>250$ & $4.03 \pm 0.08$ \\
3T3 (fibroblast) & $6.84 \pm 0.13$ & $57.28 \pm 0.10$ & $93.85 \pm 0.04$ & $0.54 \pm 0,14$ \\
\hline
\end{tabular}

Doxo: doxorubicine; $\mathrm{IC}_{50}$ : average of triplicate assays \pm standard deviation. 


\section{CONCLUSION}

The phytochemical study of $S$. mauroana aerial parts revealed that this plant accumulates several classes of secondary metabolites, like other Sinningia species previously studied. Among the isolated compounds, phenolic glycosides and flavonoids are responsible for the high antioxidant activity of ethanolic extract. On the other hand, the hexane extract shows a strong and selective activity against prostate (PC-3) human tumor cell lines, which was related with the presence of sitosterol and betulinic acid.

\section{SUPPLEMENTARY MATERIAL}

Data and spectra of NMR of isolated compounds from aerial parts of $S$. mauroana are available in http://quimicanova.sbq.org. br, as PDF file.

\section{ACKNOWLEDGMENTS}

The authors are grateful to C. B. Poliquesi for collection and identification of the plant, to the Chemistry Department (UFSM) for Gaussian09, and to CAPES (Finance Code 001), FAPESP (process numbers 16/06407-3 and 15/03726-8), and CNPq (process 304266/2017-5) for financial support.

\section{REFERENCES}

1. Chautems, A.; Dutra, V. F.; Fontana, A. P.; Peixoto, M.; Perret, M.; Rossini, J.; Candollea 2019, 74, 33.

2. Verdan, M. H.; Stefanello, M. E. A.; Chem. Biodivers. 2012, 9, 2701.

3. Verdan, M. H.; Souza, L. M.; Carvalho, J. E.; Costa, D. R. V.; Salvador, M. J.; Barison, A.; Stefanello, M. E. A.; Chem. Biodivers. 2015, 12, 148 .

4. Scharf, D. R.; Verdan, M. H.; Ribeiro, M. A.; Simionatto, E. L.; Sá, E. L.; Salvador, M. J.; Barison, A.; Stefanello, M. E. A.; J. Nat. Prod. 2016, $79,792$.

5. Verdan, M. H.; Ehrenfried, C. A.; Scharf, D. R.; Cervi, A. C.; Salvador, M. J.; Barison, A.; Stefanello, M. E. A.; Nat. Prod. Commun. 2014, 9, 1535.

6. Verdan, M. H.; Scharf, D. R.; Barison, A.; Salvador, M. J.; Stefanello, M. E. A.; Phytochem. Lett. 2017, 22, 205.

7. Amorim, M. S.; Serain, A. F.; Salvador, M. J.; Stefanello, M. E. A.; Nat. Prod. Commun. 2017, 12, 1763.

8. Verdan, M. H.; Unemoto, L. K.; Faria, R. T.; Salvador, M. J.; Sá, E. L.; Barison, A.; Stefanello, M. E. A.; Tetrahedron Lett. 2013, 54, 4735; Verdan, M. H.; Koolen, H. H. F.; Salvador, M. J.; Barison, A.; Stefanello, M. E. A.; Nat. Prod. Commun. 2015, 10, 625.

9. Soares, A. S.; Barbosa, F. L.; Rüdiger, A. L.; Hughes, D. L.; Salvador, M. J.; Zampronio, A. R.; Stefanello, M. E. A.; J. Nat. Prod. 2017, 80, 1837; Silva, A. S.; Amorim, M. S.; Fonseca, M. M.; Salvador, M. J.; Sá, E. L.; Stefanello, M. E. A.; J. Braz. Chem. Soc. 2019, 30, 2060.

10. Winiewski, V.; Verdan, M. H.; Ribeiro, M. A.; Hernandez-Tasco, A. J.; Salvador, M. J.; Stefanello, M. E. A.; J. Braz. Chem. Soc. 2017, 28, 598.

11. Barbosa, F. L; Mori, L. S.; Riva, D.; Stefanello, M. E. A.; Zampronio, A. R.; Basic Clin. Pharmacol. Toxicol. 2013, 113, 1.

12. Souza, G. V.; Simas, A. S.; Bastos-Pereira, A. L.; Frois, G. R. A.; Ribas, J. L. C.; Verdan, M. H.; Kassuya, C. A. L.; Stefanello, M. E.; Zampronio, A. R.; Plos One 2015, 10, e0117501, doi:10.1371/jornal. pone. 0117501 .

13. Lomba, L. A.; Vogt, P. H.; Souza, V. E. P.; Leite-Avalca, M. C. G.; Verdan, M. H.; Stefanello, M. E. A.; Zampronio, A. R.; Inflammation 2017, 40, 1051 .
14. Chautems, A. In Flora Fanerogâmica do Estado de São Paulo; Wanderley, M. G. L., Shepherd, G. J., Melhem, T. S., Giulietti, A. M., Kirizawa, M., eds.; Rima: São Paulo, 2003, v. 3.

15. Hay, P. J.; Wadt, W. R.; J. Chem. PhyS. 1985, 82, 270; Pedersen, T. B.; Hansen, A. E.; Chem. Phys. Lett. 1995, 246, 1; Frisch, M. J.; Trucks, G. W.; Schlegel, H. B.; Scuseria, G. E.; Robb, M. A.; Cheeseman, J. R.; Scalmani, G.; Barone, V.; Petersson, G. A.; Nakatsuji, H.; Li, X; Caricato, M.; Marenich, A.; Bloino, J.; Janesko, B. G.; Gomperts, R.; Mennucci, B.; Hratchian, H. P.; Ortiz, J.V.; Izmaylov, A. F.; Sonnenberg, J. L.; Williams-Young, D.; Ding, F.; Lipparini, F.; Egidi, F.; Goings, J.; Peng, B.; Petrone, A.; Henderson, T.; Ranasinghe, D.; Zakrzewski, V. G.; Gao, J.; Rega, N.; Zheng, G.; Liang, W.; Hada, M.; Ehara, M.; Toyota, K.; Fukuda, R.; Hasegawa, J.; Ishida, M.; Nakajima, T.; Honda, Y.; Kitao, O.; Nakai, H.; Vreven, T.; Throssell, K.; Montgomery-Jr., J. A.; Peralta, J. E.; Ogliaro, F.; Bearpark, M.; Heyd, J. J.; Brothers, E.; Kudin, K. N.; Staroverov, V. N.; Keith, T.; Kobayashi, R.; Normand, J.; Raghavachari, K.; Rendenll, A.; Burant, J. C.; Iyengar, J.; Tomasi, S. S.; Cossi, M.; Millan, J. M.; Klene, M.; Adamo, C.; Cammi, R.; Ochterski, J. W.; Martin, R. L.; Morokuma, K.; Farkas, O.; Foresman, J. B.; Fox, D. J.; Gaussian 09, Revision C01, Gaussian Inc., Wallingford, CT, 2016.

16. Salvador, M. J.; Ferreira, E. O.; Pral, E. M. F.; Alfieri, S. C.; Albuquerque, S.; Ito, I. Y.; Dias, D. A.; Phytomedicine 2002, 9, 566.

17. Prior, R. L.; Hoang, H.; Gu, L.; Wu, X.; Bacchiocca, M.; Howard, L.; Hampsch-Woodil, M.; J. Agric. Food Chem. 2003, 51, 3273; Salvador, M. J.; Ferreira, E. O.; Mertens-Talcott, S. U.; Castro, W. V.; Butterweck, V.; Derendorf, H.; Z. Naturforsch., B: J. Chem. Sci. 2006, 61, 19.

18. Mosmann, T.; J. Immunol. Methods 1983, 16, 55.

19. GraphPad Prism, version 5.00; Intuitive Software for Science, San Diego, 2007.

20. Kojima, H.; Sato, N.; Hatano, A.; Ogura, H.; Phytochemistry 1990, 29, 2351.

21. Sidjui, L. S.; Zeuko’o, E. M.; Toghueo, R. M. K.; Noté, O. P.; MahiouLeddet, V.; Herbette, G.; Fekam, F. B.; Ollivier, E.; Folefoc, G. N.; Rec. Nat. Prod. 2014, 8, 307.

22. Tanaka, J. C. A.; Vidotti, G. J.; Silva, C. C.; J. Braz. Chem. Soc. 2003, $14,475$.

23. Borroto, J.; Coll, J.; Rivas, M.; Blanco, M.; Conceptión, O.; Tandrón, Y. A.; Hernández, M.; Trujillo, R.; Plant Cell Tiss. Org. 2008, 94, 181; Ruksilp, T.; Sichaem, J.; Khumkratok, S.; Siripong, P.; Tip-pyang, S.; Chem. Nat. Prod. 2013, 49, 746.

24. Fleming, P.; O’Shea, D. F.; J. Am. Chem. Soc. 2011, 133, 1698.

25. Sheridan, H.; Nestor, C.; O’Driscoll, L., Hook, I.; J. Nat. Prod. 2011, $74,82$.

26. Massaoka, M. H.; Matsuo, A. L; Figueiredo, C. R.; Farias, C. F.; Girola, N.; Arruda, D. C.; Scutti, J. A. B.; Romoff, P.; Favero, O. A.; Ferreira, M. J. P.; Lago, J. H. G.; Travassos, L. R.; Plos One 2012, 7, e38698, doi: 10.1371/journal.pone.0038698.

27. Damtoft, S.; Jensen, S. R.; Phytochemistry 1994, 37, 441.

28. Jensen, S. R.; Phytochemistry 1996, 43, 777.

29. Lin, L.; Pai, Y.; Tsai, T.; J. Agric. Food Chem. 2015, 63, 7700.

30. Ohran, F.; Baris, O.; Yanmis, D.; Bal, T.; Guvenalp, Z.; Gulluce, M.; Food Chem. 2012, 135, 764.

31. Cai, X.-H.; Luo, X.-D.; Zhou, J.; Hao, X.-J.; J. Nat. Prod. 2005, 68, 797.

32. Cooke, R. G.; Ghisalberti, E. L.; Johnson, B. L.; Raston, C. L.; Skelton, B. W.; White, A. H.; Aust. J. Chem. 2006, 59, 925.

33. Xiao, X.-B.; Lin, Y.-X.; Xu, G.-B.; Gong, X.-B.; Gu, Y.; Tong, J.-F.; Yang, J.; Helv. Chim. Acta 2011, 94, 404; Zhong, Y.-J.; Wen, Q.-F.; Li, C.-Y.; Su, X.-H.; Yuan, Z.-P.; Li, Y.-F.; Helv. Chim. Acta 2013, 96, 1750.

34. Rios, J. L.; Recio, M. C.; J. Ethnopharmacol. 2005, 100, 80.

35. Fontanay, S.; Grare, M.; Mayer, J.; Finance, C.; Duval, R. E.; J. Ethnopharmacol. 2008, 120, 272.

36. Rana, A.; Bhangalia, S.; Singh, H. P.; Nat. Prod. Res. 2013, 27, 1167. 
37. Xiong, Q.; Kadota, S.; Tani, T.; Namba, T. ; Biol. Pharm. Bull. 1996, 19, 1580; Pan, J.; Yuan, C.; Lin, C.; Jia, Z.; Zheng, R.; Pharmazie 2003, 58, 767; Georgiev, M.; Alipieva, K.; Orhan, I.; Abrashev, R.; Denev, P.; Angelova, M.; Food Chem. 2011, 128, 100; Xue, Z.; Yang, B.; Molecules 2016, 21, 991.

38. Pietta, P.-G.; J. Nat. Prod. 2000, 63, 1035; De Marino, S.; Festa, C.; Zollo, F.; Incollingo, F.; Raimo G.; Evangelista, G.; Iorizzi, M.; Food Chem. 2012, 133, 21; Boudoukha, C.; Bouriche, H.; Elmastas, M.; Aksit, H.; Kayir, O.; Genc, N.; Senator, A.; J. Pharm. Res. Int. 2018, 22, article JPRI.40726, doi: 10.9734/JPRI2018/40726.
39. Heilmann, J.; Çalis, I.; Kirmizibekmez, H., Schühly, W.; Harput, S.; Sticher, O.; Planta Med. 2000, 66, 746; Ahmad, I.; Ahmad, N.; Wang, F.; J. Enzyme Inhib. Med. Chem. 2009, 24, 993.

40. Ramprasath, V. R.; Awad, A. B.; J. AOAC Int. 2015, 3, 1. Awad, A. B.; Burr, A. T.; Fink, C. S.; Prostag. Leukotr. Ess. 2005, 72, 219; BlancoVaca, F.; Cedó, L.; Julve, J.; Curr. Med. Chem. 2018, 25, 1.

41. Gheorgheosu, D.; Duicu, O.; Dehelean, C.; Soica, C.; Muntean, D.; Anticancer Agents Med. Chem. 2014, 14, 936; Hordyjewska, A.; Ostapiuk, A.; Horecka, A.; Kurzepa, A.; Phytochem. Rev. 2019, 18, 929. 